\title{
A YEAST IN THE FLOUR: PENTECOSTALISM AS THE AFRICAN REALISATION OF THE GOSPEL
}

\section{Joseph Quayesi-Amakye ${ }^{1}$}

Pentecost Theological Seminary, Kasoa via Accra, Ghana joeamakye@gmail.com

\section{ABSTRACT}

The paper discusses the contributions of Pentecostalism to the development of the Christian faith in Ghana and Africa. It argues that Pentecostalism is what fulfils the aspirations and quest of Ghanaian (African) Christians in their search for authentic Christian life. Christianity came to West Africa as a Western contextualised religion impinged by the nineteenth-century rationalisation, the product of the Enlightenment. This paper contends that Pentecostals influence the ethos and praxis of older mission churches in Ghana. It describes, analyses and assesses the various ways Pentecostals are helping to integrate the Christian faith into the religio-social contexts of Ghanaians. This is a complete paradigm shift from their earlier posture to social matters.

Keywords: Pentecostalism; African; gospel; catholicity; globalisation; theology

\section{INTRODUCTION}

According to a survey conducted by the Ghana Evangelism Committee in 1999, there are three major religions practised in Ghana, namely, Christianity, Islam and traditional religions. There are also non-religionists in the country. Christianity has

1 Joseph Quayesi-Amakye, (PhD, MA, Theology, VU, Amsterdam, the Netherlands; MPhil, Religious Studies, UCC, Ghana), is a Senior Lecturer and Dean of Studies, Pentecost Theological Seminary, Kasoa-Accra, Ghana. He has published two books entitled Christology and Evil in Ghana: Towards a Pentecostal Public Theology and Prophetism in Ghana Today: A Study on Trends in Ghanaian Pentecostal Prophetism, and several articles.

\section{UNISA $\cong$}


the overwhelming majority of adherents ( 8469500 ), followed by traditional/no religion (3 487 800) and Islam (2 132 700). ${ }^{2}$ In his MPhil thesis, Johnson AsamoahGyadu also noted the presence of a host of new religious movements such as Hinduism, Buddhism, Hare Krishna, and so forth, in Ghana. ${ }^{3}$ According to Apostle M. K. Ntumy, immediate past chairman of the Church of Pentecost (COP $)^{4}$ and also president of the Ghana Pentecostal Council, ${ }^{5}$ Pentecostals constitute 25 per cent of the entire Ghanaian population. ${ }^{6}$ All indications are that Pentecostalism is the most popular and most vital stream of Ghanaian Christianity. The question that arises is: How has Pentecostalism influenced the appropriation of the gospel of Christ in Ghana or Africa? Consequently, this paper seeks to describe, examine and evaluate the socio-religious contributions of Ghanaian Pentecostalism to the Ghanaian society. I will argue that Pentecostalism fulfils the quest for an authentic Christianity that satisfies Africans' socio-religious aspirations. That earlier African Christians longed for this kind of Christianity - as opposed to the staid, "alien" Western contextualised Christianity - is seen in the popularisation of Pentecostalism among the historic mission churches.

Ghana's first contact with European missionaries was in the late fifteenth century. This happened when the first Roman Catholic missionaries, who accompanied Portuguese merchants, arrived on the shores of Edina (Elmina), a village on the west coast of the Gold Coast (today's Ghana). This earliest European interaction with the natives later resulted in the Trans-Atlantic Slave Trade that carried millions of Gold Coasters to the New World. Meanwhile serious missionary work did not occur until the arrival of the Basel Mission (1828) and the Methodists (1835), among others. The missionaries combined social work with the preaching of the gospel. Consequently, they established health posts, clinics and hospitals for the natives. They also carried out literacy programmes and established schools and colleges. Ghana will forever be grateful to them for educating and training its nationalists and independence advocates. The missionaries pioneered the writing of most Ghanaian languages and translated the Christian Scriptures into local languages for converts.

The foregoing notwithstanding, converts of the mission churches often visited the traditional shrines for protection and material security. African scholars argue

2 National Church Survey: Facing the Unfinished Task of the Church in Ghana (Accra: Ghana Evangelism Committee, 1999), 39.

3 J. Kwabena Asamoah-Gyadu, "Traditional Missionary Christianity and New Religious Movements in Ghana: A Comparative Study of Attitudes toward Each Other's Faith and Practice." (MPhil thesis, University of Ghana, Legon, Accra, Ghana, June, 1994, 2-3.)

4 The Church of Pentecost is the largest Pentecostal denomination in Ghana present in over 90 countries.

5 The Ghana Pentecostal Council, now Ghana Pentecostal and Charismatic Council, is the umbrella ecumenical association of Pentecostal and Charismatic churches in Ghana.

6 M. K. Ntumy, Coming with Fire: An Autobiography of Apostle Dr M. K. Ntumy (Accra: Advocate Publishing. 2005), 206. 
that the missionaries failed to meet the superstitious aspirations of their converts. The African upheld an enchanted worldview while missionaries approached life rationally. The result was that African converts felt uncertain about the power of the Christian God amidst a world of uncertainties and demonic threats. ${ }^{7}$ Plausibly, the introduction of formal education produced half-baked Christians whose understanding of Christianity was that of elitism. The pride and pomp that Africans attached to Western education is captured in Ngugi Wa Thiong'o's novel Weep not, Child. ${ }^{8}$ As some historiographers of Ghanaian Christianity have shown, it was this spiritual vacuum that the "new Christianity" of the Pentecostals filled.

\section{CATHOLICITY AND AFRICAN PENTECOSTALISM}

After two millennia of its existence, Christ's church is gradually revealing the pluriformity of its catholicity. This is largely due to the Pentecostalisation of the church in the twentieth and twenty-first centuries. The church's catholicity has meant the doctrinal and theological symbiosis among church traditions. Catholicity does not imply an authoritarian universalist theology. It means thinking outside doctrinal and theological confines by engaging external frontiers for meaningful Christian reality. Thus, Robert J. Shreiter reviews some questions concerning universalising, contextual and liberation theologies and suggests the need for rethinking them in the face of the changed circumstances of the world. ${ }^{9}$ Consequently, he suggests that it is important to examine concepts in theology which globalisation can inform but not determine. In this regard, "theology must be able to interact with globalisation theory out of its internal history and resources and not be simply reactive to it." ${ }^{10}$ Hence, Shreiter proposes catholicity as the most appropriate theological concept for the church in a globalised world. Catholicity dates back to the Council of Constantinople and the Nicene Creed.

Meanwhile a discussion on catholicity demands intercultural communication and hermeneutics. Moreover, the church's marks need not be restricted to deductive uses. Therefore, it is imperative to modify the degree to which a theology of the marks has been developed and used historically. With the church's global expansion and commitment to inculturation of the gospel we must come to a heuristic understanding of what catholicity means. Historically, catholicity has had different meanings such as fullness and orthodoxy, of extendedness and even identification with Empire,

7 Osadolor Imasogie, Guidelines for Christian Theology in Africa: Theological Perspectives in Africa (Achimota: ACP Press 1995), 47-53.

8 Ngugi Wa Thiong'o, Weep not, Child (London: Heinemann Educational Books, 1964), 3-4, 12, $15-18$.

9 Robert J. Shreiter, The New Catholicity: Theology between the Global and the Local (Maryknoll, New York: Orbis Books, 2004), 118.

10 Shreiter, The New Catholicity, 118. 
of juridical bond and conformity, of the partial and visible manifestation of the completeness and yet-to-be-revealed Lordship of Christ.

Whenever the circumstances under which people lived changed, their sense of theology also changed. Shreiter believes that it is important to explore the church's self-understanding of its catholicity in the world. Put differently we must examine the church's mission and self-understanding of evangelisation. ${ }^{11}$ The new catholicity of the whole church can thrive when local faith communities approach inculturation with generosity for inherited traditions of the church. Indeed, the new catholicity demands reciprocal understanding of the message between the communicator and receiver of the gospel. This will forestall the underestimation of local cultures' ability to appropriate the gospel. ${ }^{12}$ Our encounter with Ghanaian Pentecostals will reveal that they consistently adapt their gospel to the needs of their receptor cultures. This rationalises the Pentecostal movement as a popular religion among citizens.

Second, people like to live and experience culture as an integrated whole. Meanwhile globalisation tends to increase asymmetries in the communication process. These asymmetries call for the church's attention and sensitivity. Churches must seek to eliminate socio-economic and religio-cultural asymmetries in our societies. Whether classical or neo, Pentecostals are making efforts to deal with these asymmetries by offering a gospel that answers the needs of Ghana's suffering masses. The internationalisation of Ghanaian Pentecostalism has meant theological, economic, psychological, ecclesiological and evangelistic co-operation with external faith communities and individuals.

Third, emerging Pentecostal ecclesiology in Ghana shows what Shreiter calls a new theology of culture. It shows a commitment to the struggle with the centrifugal forces pressing down upon cultures. Thus, the globalisation of Ghana's Pentecostalism has meant the accommodation of cultural shifts in the country's rapidly growing youth population. This "accommodating" and liberalised ecclesiology is confronted with two realities: guarded "orthodoxy" versus liberalism. Indeed, as Ghanaian Pentecostals aptly demonstrate, theology succeeds on orthopraxis and orthodoxy.

Our ability to proffer appropriate answers to our contexts will demonstrate how prepared and willing we are to invent new and better images about ourselves as God's children. A relevant Ghanaian or African theological enterprise must analyse the indigenous religio-cultural understanding to see how it interfaces with the Christian gospel. This is exactly how Ghanaian Pentecostalism empowers its adherents to engage their existential fears with their understanding of the Christian message.

Ghana belongs to those regions where the Pentecostal faith thrives and continues to claim fresher territories. It is even now acknowledged that Christianity

11 Shreiter, The New Catholicity, 121-2.

12 Shreiter, The New Catholicity, 129, 132. 
has shifted from the global centre to the global south, like Africa. ${ }^{13}$ The success of African Pentecostalism is linked to its ability to contextualise the gospel with ease. ${ }^{14}$ Pentecostalism is pervasive in Africa because it is able to interface with the primal cosmology. Being sympathetic to local cultures, Pentecostalism fulfils Christianity's natural propensity to survive when it takes roots in recipient cultures. ${ }^{15}$

Today, Africa's bourgeoning and enterprising Pentecostal churches are championing the "reverse missions" in the West. But it is wrong to think that Pentecostalism is a homogenous religion; it is as heterogeneous in character as it is in mission. For instance, in Ghana, Classical Pentecostalism has gradually lost its monopoly to the neo-Pentecostal churches or Charismatic Ministries/Churches $(\mathrm{CMs} / \mathrm{CCs})$ that began in the late 1970s. ${ }^{16}$ Indigenous Classical Pentecostalism in Ghana is traceable to the combined evangelistic efforts of native Apostle Peter Anim and the UK Apostolic Church Irish missionary James McKeown in the 1930s. ${ }^{17}$ Over time, the $\mathrm{CMs} / \mathrm{CCs}$ have nuanced diversely, resulting in the New Prophetic Churches (NPCs) with a strong prophetic ethos. ${ }^{18}$ Indeed, prophetic fellowships or centres now characterise Africa's Christianity both within Pentecostalism and mainline historic churches. ${ }^{19}$ These fellowships or prayer centres have become hubs of Christian hope and salvation for the socio-economically weary in African society. Whereas typical CMs took for their starting point and championed North Atlantic gospel of prosperity with diverse emphases, the NPCs replicate more or less characteristic traits of the older African Initiated/Indigenous/Independent Churches (AICs).

Clearly, Pentecostalism has created a niche for itself among Africans. The success of the movement lies in its ability to influence and change the African religious and social terrain. As I argue in several of my works, Pentecostalism has become so extremely ubiquitous in Africa, that it is becoming difficult to dichotomise churches in terms of theological and liturgical considerations. For a movement that started on

13 David Barrett, “AD 2000: 350 Million Christians in Africa?" International Review of Mission (1970): 50.

14 Ogbu U. Kalu, "African Christianity: An Overview," in African Christianity: An African Story, edited by Ogbu U. Kalu, (Trenton, NJ and Asmara, Eritrea, Africa World Press Inc., 2007), 37.

15 Azonse Uka, "African Christianities: Features, Promises and Problems," Arbeitspapiere/Working Papers, 79. Department of Anthropology and African Studies. Johannes Gutenberg-Universitat, (2007): 3.

16 See Kwabena Asamoah-Gyadu, African Charismatics: Current Developments within Independent Indigenous Pentecostalism in Ghana (Leiden: E.J. Brill, 2005); Paul Gifford, Ghana's New Christianity: Pentecostalism in a Globalizing African Economy (London: Hurst and Co., 2004), viii, ix.

17 R. W. Wyllie, "Pioneers of Ghanaian Pentecostalism: Peter Anim and James McKeown," Journal of Religion in Africa. 6 no. 2 (1974): 109.

18 Joseph Quayesi-Amakye, "Prosperity and Prophecy in African Pentecostalism." Journal of Pentecostal Theology 20 (2011): 293.

19 Joseph Quayesi-Amakye, "Christ, Evil and Suffering in Ghanaian Christian Liturgy." PentecoStudies: An Interdisciplinary Journal for Research on the Pentecostal and Charismatic Movements, 14, no.1 (2015): 15. 
derision and spite, it is almost a surprise, if not a wonder, that it has succeeded to dictate the religious tempo of Christianity in Africa.

In their nascent stages Pentecostal churches earned the unenviable accolade as witches' churches because of their overt and uncontrolled manifestations of Holy Spirit possession. The phenomenon was actually the by-product of their uncompromising and dogmatic stress on speaking in tongues as the imperative sign of Spirit baptism among believers without which salvation was impossible or at best incomplete. Pentecostals view Peter's contextualisation of Joel's prophecy (Acts 2:17-18) as the watershed for Christian prophetism. Joel had predicted a pneumatic proliferation that would defy social barriers. The descent of the Spirit would mean barrier breaking at all fronts: religious, cultural, and social. It would also mean the constitution of a new people of God: Jews and Gentiles. Consequently, Pentecostal mission takes inspiration from this first Pentecost.

Pentecostalism stresses the continual presence and activeness of the Holy Spirit in the church's life throughout the ages. Pentecostals believe that the Spirit's active presence becomes most evident through believers' reception and experience of Spirit Baptism. It is believed that generally such experience must be accompanied by speaking in tongues or glossolalia. Of course, early Pentecostals mistook glossolalia for xenoglossa (real languages previously unknown to the recipient). The idea was claimed and promoted by Charles F. Parham, the formulator of tongues as the biblical evidence of Spirit baptism. Convinced thus, early American Pentecostals embarked on fruitless world missions. ${ }^{20}$

Meanwhile there ranges a debate concerning the paradigmatic nature of Spirit baptism. The debate has hovered around whether Spirit baptism is a conversion/ initiation experience or a subsequent experience for believers. Is it an individualised, personalised experience, or an eschatological, corporate, and barrier-breaking event? ${ }^{21}$ Some like H. R. Dunning think that the Spirit's work in Luke-Acts must be interpreted in moral and prophetic terms. ${ }^{22}$

\section{SOCIO-RELIGIOUS IMPORTANCE OF PENTECOSTALISM}

In the early stages of the Pentecostal movement in Ghana, some converts were "runaway" members of the mainline churches. They joined the Pentecostal

20 See Sarah E. Parham, The Life of Charles F. Parham (Joplin, MO: Tri-State Printing Co., 1930 reprinted, Birmingham, AL: Commercial Printing Co., 1977), 53-54.

21 Cf. A. W. Zwiep, The Ascension of the Messiah in Lukan Christology (Leiden: E.J. Brill, 1997), 175-185; B. Witherington, The Acts of the Apostles: A Socio-Rhetorical Commentary (Grand Rapids, MI, Cambridge: Eerdmans; Carlisle: Paternoster, 1998), 132.

22 H. R. Dunning, Grace, Faith, and Holiness: A Wesleyan Systematic Theology (Kansas City: Beacon Hill, 1988), 418-424. 
churches in search of what they considered to be a more meaningful and responsive Christianity to their existential fears and needs as African religious people. So, naturally it was unsurprising that their former churches should take a swipe at the beneficiary Pentecostal churches that, as it were, were opportunistic in cashing in on their labours to grow and expand their human, economic and material fortunes.

The "Pentecostal invasion" became a disguised blessing to the historic churches because to stem the tide of membership outflow they carried out some introspections and diagnoses of the problem on hand. Initially, it was believed that, like the earlier African Initiated Churches, the Pentecostals attracted converts because they used African traditional musical instruments and idioms in communicating the gospel. This led to a re-examination of the historic churches' paternalistic inherited Western church liturgies. Consequently, emulating the Pentecostals they introduced African musical forms and instruments into their liturgy and worship. While this met the aspirations of members halfway, it was apparent that their spiritual needs still went unsatisfied. This is because music alone does not solve spiritual problems (like the fear of witchcraft) or heal diseases believed to be esoteric. It is no wonder that eventually the historic churches adopted and incorporated spiritual activities and programmes akin to the Pentecostal churches.

Scholars from the mainline stable have shown that to hold their own Ghana's (and by extension, Africa's) mainline historic churches have had to accept and incorporate Pentecostal practices and concepts, and this has contributed largely to the Pentecostalisation of the country's Christianity. ${ }^{23}$ In a way this new development in the mainline churches sought to make the Christian faith more relevant, or to "incarnate" it in idioms easily understood and appreciated by Africans. The point is that African Christians have begun to appreciate the need for "reformulating the Christian faith drawing on aspects of primal imagination". ${ }^{24}$ As the older churches embarked on their new ecclesiological journey, it became abundantly clear that the Pentecostals had discovered what had eluded them (the older churches) for a long time.

From the late 1970s, the CMs have contextualised the gospel as the panacea to socio-economic needs and problems of Africans. For instance, in Ghana, their efforts appeared in different phases: faith gospel from the late 1970s; deliverance gospel in the late 1980s and early 1990s; and prophetic gospel from the 1990s to date. Ghana's brand of prosperity gospel may be assessed in relation to the national economic crises of the 1970s-1990s. Typically, during the dictatorial dreadful military regime of the

23 See for example, Cephas N. Omenyo, Pentecost outside Pentecostalism: A Study of the Development of Charismatic Renewal in the Mainline Churches in Ghana (Zoetermeer, the Netherlands: Boekencentrum Publishing House, 2006); J. Kwabena Asamoah-Gyadu, Contemporary Pentecostal Christianity: Interpretation from an African Context (Oxford: Regnum Books International, 2013), 65-86.

24 Kwame Bediako, Christianity in Africa: The Renewal of a Non-Western Religion (Edinburgh: Edinburgh University Press, 1995), 104. 
Provisional National Defence Council (PNDC, 1980s-1990s), the country grovelled under the International Monetary Fund's Structural Adjustment Programme. During the period, the lives of Ghanaians worsened. Several factors combined to create this. First, there was labour retrenchment and high cost of living. Second, there was a nation-wide famine resulting from a sudden and inexplicable inferno that destroyed agricultural lands. Third, thousands of Ghanaians were expelled from Nigeria in 1983, which strained the already ailing economy. In the midst of the socioeconomic and political uncertainties, Ghanaians organised community and office Christian fellowships to pray for the nation. It was into this socio-religious space that enterprising charismatic young people entered to found today's CMs. With no serious signs of socio-economic betterment of Ghanaians, the CMs continue to grow and expand with innovative spiritual and economic empowerment programmes.

As may be expected, the entrepreneurial skills of the CMs resulted in the development of a very appealing popular Christianity for African youth. The theology of CMs' preachers has been identified as the re-echoing of North American prosperity gospel and Nigerian demonology gospel. The basic argument of this gospel is that God has met all the needs of believers and that this can be appropriated through positive confession of faith and application of right spiritual formulas ${ }^{25}$ Nowadays, the NPCs are influencing the prosperity gospel of the CMs. In the NPCs prosperity is achieved via the prophetic word and ritualism.

The proliferation of prophetism in Africa may be tied to the African curiosity about the unexplained situations of life. Therefore, Africans, Christians or nonChristians, explore sources of vital forces to positivise their destinies or fate. Thus, "Christianised" and "civilised" African curious minds resort to Christian and other religious mystics to elicit particularised data. Yet, because of its particular modus operandi, contemporary Pentecostal prophetism has elicited a lot of suspicions and doubts among many Ghanaians. That concerned citizens are uncomfortable with the prophets is a fact that cannot be glossed over. Thus, commentators on African Pentecostal prophetism like Fainos Mangena and Samson Mhizha castigate practitioners as "white collar prophets" who "professionalise the word of God through monetising it." ${ }^{26}$ The atmosphere in which this prophetic monetisation operates is the general Pentecostal imaging of Jesus Christ as the All-powerful who saves people from their troubles, including poverty. ${ }^{27}$

25 Paul Gifford, African Christianity: Its Public Role (London: C. Hurst and Co. Ltd., 1998), 39.

26 Fainos Mangena and Samson Mhizha, "The Rise of White Collar Prophecy in Zimbabwe: A Psycho-Ethical Statement," in Prophets, Profits and the Bible in Zimbabwe, edited by Ezra Chitando et al., (Bamberg: Bamberg University Press, 2013), 136.

27 Ogbu U Kalu, "Preserving a Worldview: Pentecostalism in the African Maps of the Universe." Pneuma, 24, no. 2 (2002): 110-137; Klaus Hock, "Jesus power-super power: on the interaction between Christian fundamentalism and new religious movements in Africa." Mission Studies 12, no. 1 (1995): 56-70 
Meanwhile the apparent capitalist orientation and tendencies of prosperity preachers have won them more foes than friends. Critics reject it for being an inadequate and lopsided understanding of what religion is. In my view some critics just delight in criticising prosperity preachers without doing due diligence to the situation on the ground, at least in the African context. Attention must be paid to what the preachers are saying vis-à-vis the African problems, since it is not part of authentic Christianity to promote poverty. At times some of the critics are themselves guilty of exploiting their people in the name of doing the Lord's work. Granting that prosperity preachers interpret and apply biblical texts disparately, there is no gainsaying the fact that no sincere Christian, critics inclusive, can claim to be satisfied with material and financial blights that Africans generally suffer. In any case, the goal of theology is to make people experience God mundanely. ${ }^{28}$ Theology is contextual; and a failure to uphold an unchanging theological ground stands condemned and crumbles before people's existential realities. Globally, there are radical voices raised against so-called Universalist theology for its narrow understanding of salvation. Genitive theologies are uncomfortable with traditional theology's soul salvation to the neglect of other aspects of human life..$^{29}$ To the genitive theologian, any limitation of salvation to soul salvation is narcissistic, pretentious and suspicious.

\section{IN THE WORLD BUT NOT OF THE WORLD}

Like many Africans, Ghanaian Pentecostals conceive the world as a place of suffering. To them unrestrained suffering has personal and communal ramifications. Suffering, thus, may appear as ill-health, poverty, childlessness, premature deaths, bad marriages, demonic suppression and oppression, bankruptcy, low agricultural yield, demotion, joblessness, rebellion in children, and all forms of difficulties and failures in life. This makes suffering a spiritual bondage that calls for deliverance by a supernatural power. To Pentecostals, sin is at the root of all suffering in this life. But what do Pentecostals mean by sin? The basic Pentecostal understanding of sin is moral and spiritual deficiency that undermines the divine-human relationship.

However, sin is not just moral deficiency. It can actually be social in dimension. At least this is the position of such Charismatic preachers like Dr Mensa Otabil, who

\section{Shreiter, The New Catholicity, 105-6.}

29 See for example, Gustavo Gutierrez, "Toward a Theology of Liberation," in Liberation Theology: A Documentary History, edited by Hennelly, Alfred T., S.J. (Maryknoll, N.Y: Orbis Books, 1990); Gustavo Gutierrez, A Theology of Liberation: History, Politics and Salvation (Maryknoll, N.Y: Orbis Books, 1973); Leonardo Boff and Clovodis Boff, Introducing Liberation Theology (Maryknoll, N.Y: Orbis Books, 1988). 
identifies the causes of poverty as social injustice and inequity. ${ }^{30}$ This view is shared in a greater or lesser degree by many Pentecostals who believe that this world is an arena of inequity and oppression. The powerful take advantage of the weak and poor. Even spouses are defrauded of their partners by smart and greedy persons. People lose jobs for standing for truth and honesty. A place of bondage indeed!

Similarly, Classical Pentecostal pastors like Apostle Dr Alfred Koduah, the immediate past general secretary of COP, also argue that there is more to what is traditionally classified as sin. To this end, Apostle Koduah expands the idea of sin to cover all irresponsible attitudes towards the nation and community that deprive the nation of its needed socio-economic and political development and advancement. ${ }^{31}$ Thus, Pentecostals believe that soul salvation is not to be the only focus of the Christian. There must be a blanket condemnation of all forms of wickedness that cover the deeds of insensitive employers, corrupt and unfaithful employees, corrupt pastors/church leaders, corrupt politicians and unfaithful married persons who cheat on their partners for economic advantage.

Needless to say, these rigorous attitudes of Pentecostals have effectively produced in many Pentecostals a unique sense of right and responsible living. Many have become conscious of the devastations of sin and the need to live holy and righteous lives. Indeed, many have come to appreciate that sin deceives; its expectations, hopes, assurances, and fulfilment are all false. Again, it pretends to be pleasurable whereas in reality it blinds one of the realities of life by hiding its inherent dangers and associated psychological pains and agony. It is always spiritually and physically disastrous. The dehumanising effects of sin make it necessary to look for liberation. The utter necessity of eternal salvation explains why Pentecostals conduct Altar Calls for prospective converts to respond to the call of God. ${ }^{32}$

In Ghanaian Pentecostal understanding there is a close link between economic wellbeing and physical health. The Pentecostal desire for economic empowerment and abhorrence of poverty must be placed within the Ghanaian socio-economic contexts where poverty is considered antithetical to human wellness. Poverty creates "de-definition" or "re-identification" in the social strata. This means a loss of socioeconomic and political identity of an individual(s). It includes not only poverty, but sickness and disease, adversity, and so forth. This again results in "re-identification" of the poor, the sick, the disadvantaged who are marginalised and ostracised, to acquire a new name, a new face and a new identity in society. This is an effective means of socio-economic and political stratification that affords the rich and powerful

30 Mensa Otabil, the general overseer of Ghana's leading charismatic church, the International Central Gospel Church, said this as part of a paper he delivered at the "Awaken to the Word VIII: Challenging the Church for Meaningful Missionary Work" Seminar held at the Bethany Methodist Church, Dzorwulu, Accra, Ghana March 26, 2009.

31 Alfred Koduah, Who is Disturbing the Nation? (Accra: Advocate Publishing Limited, 2008).

32 After sermons Ghanaian churches invite sinners to give their lives to Jesus Christ. Such sessions are called Altar Calls. 
to heavily exploit the needy. There is, therefore, a disavowal of poverty, diseases and sicknesses among Ghanaian Pentecostals. In the minds of Ghanaian Pentecostals:

\begin{abstract}
Poverty defaces, depreciates, depersonalises, downgrades and humiliates. Both poverty and ill-health produce insignificance; create hunger, thirst, and non-existence. They also produce death and dearth. Poverty deprives people of their desirables (ohia tua akonnodee). People therefore consult oracles and Christian prophets for material prosperity, success, wealth, health and protection. Poverty literally reduces an adult to the status of a child. And it is poverty which makes the elder serve the younger at the family levels. A poor person is brother to a fool; his or her word is not valuable in the family, community and society. Poverty is madness but riches and wealth invite blood (life)! So goes a popular secular song. Diseases and sicknesses reduce one to a state of dependency and that may be exploited by one's wicked enemies. ${ }^{33}$
\end{abstract}

It is against this background that many Pentecostal/Charismatic churches preach the so-called prosperity gospel that often seeks to challenge adherents to adopt positive attitudes to life. This means the swapping of all tendencies of laziness, ineptitude, slackness, diffidence and fatalism for industry, discipline, hard work, faith, selfbelief and purpose, among many others. It also means faithfulness and commitment to the things of God, one's relationships, skills acquisition, educational pursuit and generally a positive attitude to life. It is in line with this that some churches and individuals have set up schools/universities to boost the manpower resources of the country. Many Pentecostal churches and individuals have established clinics, health centres, hospitals and basic and high schools to revamp government's efforts in these areas.

If Pentecostals are focused on economic empowerment, it is because of their strong conviction that wealth affirms, dominates, controls and commands respect. It is audacious, powerful, imposing, eloquent, and vociferous. It reshapes, reaffirms and personalises. It commands submission and audience, refines status and elicits fear. The rich and wealthy are adored and are served at their beckon. Young or old, the wealthy command authority and power. We live in a world of power and the powerful are the rulers; the poor have no place in this world of power. Because of wealth some nations become rulers over others. Class definition also comes about in societies when there is inequality in the distribution of resources and wealth. For Ghanaian Pentecostals, the Bible holds the key to the socio-economic emancipation and re-modification of Ghanaians.

Socio-economic emancipation implies Christian stewardship of the resources that God has bestowed for our wellbeing. We have already shown above how Apostle Koduah sees irresponsible attitudes as a disturbance to the welfare of the nation. However, the idea of stewardship is not restricted only to socio-economic facets of the society, but extends to the nation's political sphere as well. Today, there

33 Joseph Quayesi-Amakye, "Ideas of the Divine and the Human in Ghanaian Pentecostal Songs," (MA thesis, Vrije Universiteit, Amsterdam, the Netherlands, 2008, 33.) 
has been a drastic paradigm shift in relation to Ghanaian Pentecostals' attitude to nation building - including politics. A number of Pentecostal/Charismatic pastors, church leaders and members are involved in the country's politics. In fact, Apostle Professor Opoku Onyinah, current chairman of the COP and president of the Ghana Pentecostal and Charismatic Council, is a member of the Peace Council, an ecumenical religious council that is tasked with ensuring political cohesion in Ghana. Whether all Ghanaians appreciate the council's contributions and efforts, is a matter for the public to assess. What is important to us is that his inclusion on the council is a clear demonstration of a paradigm shift in Ghanaian Pentecostals' public theology. Indeed, his show of patriotism indicates that Pentecostals have come of age politically.

\section{CONCLUSION}

It is believed that the Pentecostal movement is the fastest growing and most vivacious strand of Christianity globally. ${ }^{34}$ It is also the strand of Christianity that presently takes the receptor cultures seriously in its missionary enterprise. Perhaps it may not be far-fetched to say that Christianity must be thankful to God for various Pentecostal "irruptions" in different parts of the world. That the appearance of Pentecostalism was the act of providence cannot be overstated; for through the movement the faith has escaped extinction in spite of the myriad of attacks on its life. Several factors have been attributed to the success story of Pentecostalism, such as its popularity, verbal theology, conscious pneumatic expression, normalisation, existential concerns and ability to adapt to recipient cultures. Ghanaian Pentecostals are demonstrating that Christian salvation must garb both spiritual and mundane attires for holistic religiosity. Finally, it is vital for the church's fullness of faith in a new catholicity to undertake a major theological project in a globalised world by offering a number of theological teloi to guide humanity and society. ${ }^{35}$ Hence, Ghanaian Pentecostals' ability to offer a telos that draws on the eschatological possibilities to the mundane realities of the Chrisitian faith, is indeed very integral to a new catholicity.

\section{REFERENCES}

Asamoah-Gyadu, J. Kwabena. "Traditional Missionary Christianity and New Religious Movements in Ghana: A Comparative Study of Attitudes toward Each Other's Faith and Practice.” MPhil thesis, University of Ghana, Legon, Accra, Ghana, June, 1994.

Asamoah-Gyadu, J. Kwabena. African Charismatics: Current Developments within Independent Indigenous Pentecostalism in Ghana. Leiden: E.J. Brill, 2005.

34 P. Jenkins, The Next Christendom: The Coming of Global Christianity (Oxford: Oxford University Press, 2002), 8.

35 Shreiter, The New Catholicity, 131. 
Asamoah-Gyadu, J. Kwabena. Contemporary Pentecostal Christianity: Interpretation from an African Context. Oxford: Regnum Books International, 2013.

Barrett, David. “AD 2000: 350 Million Christians in Africa?” International Review of Mission, 1970.

Bediako, Kwame. Christianity in Africa: The Renewal of a Non-Western Religion. Edinburgh: Edinburgh University Press, 1995.

Boff, Leonardo and Clovodis Boff. Introducing Liberation Theology. Maryknoll, N.Y: Orbis Books, 1988.

Chitando, Ezra et al (Eds.). Prophets, Profits and the Bible in Zimbabwe. Bamberg: Bamberg University Press, 2013.

Dunning, H. R. Grace, Faith, and Holiness: A Wesleyan Systematic Theology. Kansas City: Beacon Hill, 1988.

Gifford, Paul. African Christianity: Its Public Role. London: C. Hurst and Co. Ltd., 1998.

Gifford, Paul. Ghana's New Christianity: Pentecostalism in a Globalizing African Economy. London: Hurst and Co., 2004.

Gutierrez, Gustavo. A Theology of Liberation: History, Politics and Salvation. Maryknoll, N.Y: Orbis Books, 1973.

Gutierrez, Gustavo. “Toward a Theology of Liberation.” In Liberation Theology: A Documentary History Hennelly, edited by Alfred T. Maryknoll, N.Y: Orbis Books, 1990, 62-76.

Hock, Klaus. "Jesus power-super power: On the interaction between Christian fundamentalism and new religious movements in Africa." Mission Studies, 12 no.1 (1995): 56-70.

Imasogie, Osadolor. Guidelines for Christian Theology in Africa: Theological Perspectives in Africa. Achimota: ACP Press 1995.

Jenkins, P. The Next Christendom: The Coming of Global Christianity. Oxford: Oxford University Press, 2002.

Kalu, Ogbu U. "Preserving a Worldview: Pentecostalism in the African Maps of the Universe." Pneuma, 24 no. 2 (2002): 110-137.

Kalu, Ogbu U. "African Christianity: An Overview.” In African Christianity: An African Story, edited by Ogbu U. Kalu. Trenton, NJ and Asmara, Eritrea, Africa World Press Inc., 2007.

Koduah, Alfred. Who is Disturbing the Nation? Accra: Advocate Publishing Limited, 2008.

National Church Survey: Facing the Unfinished Task of the Church in Ghana. Accra: Ghana Evangelism Committee, 1999.

Ntumy, M. K. Coming with Fire: An Autobiography of Apostle Dr. M. K. Ntumy. Accra: Advocate Publishing. 2005.

Omenyo, Cephas, N. Pentecost outside Pentecostalism: A Study of the Development of Charismatic Renewal in the Mainline Churches in Ghana. Zoetermeer, the Netherlands: Boekencentrum Publishing House, 2006.

Parham, Sarah, E. The Life of Charles F. Parham. Joplin, MO: Tri-State Printing Co., 1930 reprinted, Birmingham, AL: Commercial Printing Co., 1977.

Quayesi-Amakye, Joseph. "Ideas of the Divine and the Human in Ghanaian Pentecostal Songs." MA thesis, VrijeUniversiteit, Amsterdam, the Netherlands, 2008. 
Quayesi-Amakye, Joseph. "Prosperity and Prophecy in African Pentecostalism.” Journal of Pentecostal Theology 20 (2011): 92-116.

Quayesi-Amakye, Joseph. "Christ, Evil and Suffering in Ghanaian Christian Liturgy." PentecoStudies: An Interdisciplinary Journal for Research on the Pentecostal and Charismatic Movements, 14 no. 1 (2015): 9-41.

Shreiter, Robert, J. The New Catholicity: Theology between the Global and the Local. Maryknoll, New York: Orbis Books, 2004.

Uka, Azonse. “AfricanChristianities: Features, Promises and Problems.” Arbeitspapiere/Working Papers, 79. Department of Anthropology and African Studies. Johannes GutenbergUniversitat, 2007.

Wa Thiong'o, Ngugi. Weep not, Child. London: Heinemann Educational Books Ltd. 1964.

Witherington, B. The Acts of the Apostles: A Socio-Rhetorical Commentary. Grand Rapids, MI, Cambridge: Eerdmans; Carlisle: Paternoster, 1998.

Wyllie, R. W. "Pioneers of Ghanaian Pentecostalism: Peter Anim and James McKeown.” Journal of Religion in Africa, 6 no. 2 (1974): 109-22.

Zwiep, A. W. The Ascension of the Messiah in Lukan Christology. Leiden: E.J. Brill, 1997. 